\title{
A Historical-Critical and Morpho-Synthatic Interpretation of Luke 4:18-19
}

\author{
Patrick Yankyera, Jonathan E.T. Kuwornu-Adjaottor, Emmanuel Kojo Ennin Antwi \& Frimpong Wiafe ${ }^{1}$ \\ ${ }^{1}$ Department of Religious Studies, Kwame Nkrumah University of Science and Technology, Kumasi-Ghana.
}

\begin{abstract}
This paper examines the meaning of Luke 4:18-19 using the historical-critical method to establish the meaning of the text under study. The objective here is to investigate the origins of the pericope to understand "the world behind the text" as well as its applicability in contemporary Pentecostal/Charismatic churches in Ghana. This paper contends that finding out the accurate meaning of biblical text is relevant for Christian life and ministry. It discovers that Jesus makes it known that he is the focus of the foretold word of Isaiah. This confirms that he is the carrier of the Spirit, the gospel's proclaimer, the eschatological prophet and the one who comes to set the oppressed free. He was bestowed with all the Spirit's gifts and graces, not by measure, as it was on Old Testament kings, priests and prophets but by divine unction. The paper concludes that Jesus' claim of having been mandated by God to accomplish the task of preaching salvation to humanity. His identification with the promised Messiah in the Isaianic prophecies indicates that he was commissioned and empowered to carry out a holistic ministry which involves not only preaching salvation but also meeting the social needs of people he encountered. The study recommends that proper interpretation of Scripture using the right tools should be adopted in order to ascertain the right meaning of biblical text such as Luke 4:18-19 for application. The study contributes to research knowledge on the holistic approach to ministry pointing out clearly that the ministry is not only for the spiritual growth of a person but also a person's social wellbeing.
\end{abstract}

Keywords: Interpretation, Anointing, Gospel, Acceptable Year of the Lord.

\section{Correspondence: \\ Patrick Yankyera \\ Email: patrickyankyera@gmail. \\ com}

\section{Publication History}

Received 27th August 2020,

Accepted 24th September 2020,

Published online 6th

October 2020.

(C) 2020 The Author(s). Published and Maintained by Noyam Publishers.

This is an open access article under the CCBY license (http://creativecommons.org/licenses/by/4.0/).

\section{INTRODUCTION}

The uniqueness of Luke's Gospel can be identified in two different ways. Foremost, it is noted to be the longest and with the book of Acts, his work consists of about 28 percent of the New Testament canon. ${ }^{2}$ Not only does Luke make known to Bible readers Jesus and His ministry, but also, he introduces the relationship between that ministry and the early church era. This connection therefore helps him to deliberate on how the salvation of God came about in Jesus and how the early church comprehended and proclaimed Jesus. Luke, a New Testament writer and the only Gentile, constantly directs his focus on the evolvement and growth of the early Church, to be specific and the Church as a whole and as a body of missions, bringing into fulfillment Jesus' command to propagate the gospel. Luke's gospel places an emphasis on the marginalized which comprises destitute people, women, social outcasts and children. This emphasis was however, the concern of Jesus. ${ }^{3}$

\section{METHODOLOGY}

The study employed the exegetical approach in studying critically the selected text. In line with this, methods used for biblical studies and analysis were employed on the text. This study employed the Historical Critical Method in an

\footnotetext{
Charles H. H. Scobie, “A Canonical Approach to Interpreting Luke," in Reading Luke: interpretation, Reflection, Formation, ed. Craig Bartholomew, Joel B. Green, and Anthony Thiselton, Scripture and Hermeneutics 6 (Milton Keynes: Paternoster, 2005), 331.

3 Donald Stamp and Wesley J. Adams Fire Bible: Global Edition (Springfield: Hendrickson Publishers Marketing, LLC, 2009$), 1821$.
} 
attempt to understand the world behind the text. This method suggests that the meaning of a text is the author's intended meaning and that the author's intention could be derived most accurately by observing the facts of history and rules of grammar as they apply to the text being studied. ${ }^{4}$ The historical critical method was chosen for this study because the concern of the proponents of these critical apparatus was not about the text per se but the history behind the text. ${ }^{5}$ Thus, historical-critical approaches discuss the world of the author vis-a-vis the culture, the language and the social background of the Bible world. ${ }^{6}$ The historical-critical studies are based on sound conviction that in order for one to understand the meaning of scripture for today, one must first understand its meaning for the original readers. ${ }^{7}$

To be able to unravel approximate intended meaning of the original author, the study employed the morphological and syntactical analysis approach in order to determine more accurately the author's intended meaning. A syntactical analysis is understood by scholars as the study of the meaning of the individual words (lexicology) and the way those words are combined (syntax), in order to determine more accurately the author's intended meaning. According to Henry A. Virkler, Lexical-syntactical analysis does not encourage blind literalism: it recognizes when an author intends his or her works to be understood literally, when figuratively, and when symbolically, and then interprets them accordingly. ${ }^{8}$

\section{FINDINGS AND DISCUSSION}

In an attempt to arrive at the proper interpretation and application of Luke 4:18-19, the paper came up with the following findings which are analysed alongside.

\section{Immediate Context}

The gospel account as recorded in Luke 3 and 4 indicates that after Jesus' baptism in the River Jordan where the Holy Spirit came upon him (Lk 3:21-22), he was led to the desert to be tempted by the devil (Lk 4:1-2). After this encounter, Jesus returned to Galilee, and the crowds followed him because news about his miracles and unique teaching with authority had spread throughout the entire region (Lk 4:14). Jesus then went to Nazareth where he grew up, and when it was Sabbath, he went to the synagogue for worship as usual. It was at this synagogue worship that upon invitation to read and teach the Scriptures, Jesus took the scroll and read from the prophet Isaiah, as later recorded in Luke 4:18-19. As part of the service, the Lord had the opportunity to share from the prophets and he decides to read from Isaiah 62:12. In other words, Jesus was quoting a prophecy from the scrolls declared by the prophet Isaiah as the main text for his sermon.

Contrary to the assertion by some commentators that the text from Isaiah 61 was selected for Jesus to read, Uwaegbute argues that the Greek verb used rather supports the contrary. He points out that the aorist passive heuren, ( $3^{\text {rd }}$ person singular) as used is translated 'He found.' This verb heuren indicates that Jesus himself chose reading Isaiah 61:1-2 when the scroll was handed to him by the chazzan (attendant). ${ }^{9}$ He further asserts that the prevailing oppression and harsh living conditions of the Jews probably inspired Jesus to make that particular choice as his action plan for his ministry which he read in Luke 4:16-21. ${ }^{10}$ The position of this study is that although Jtesus responded directly to many socio-economic and political ills during his earthly ministry, the subject of his Mission Statement on earth was divinely predetermined. The choice of Isaiah 61 to inaugurate his mission on earth was thus not an after-thought instigated by the happenings around him, but divinely inspired. Furthermore, in his divinity, Jesus was aware and clear about his mission on earth, and hence it was not a coincidence at all that he read Isaiah 61. There was a divine providence in that portion of scripture that it should be read that day, and he used it to outline the primary purpose of his ministry. It is evident from Luke's narrative that the author intended to introduce the public ministry of Jesus with emphasis not only on his preaching but also the context for his ministry.

\section{Morpho-syntactic Analysis of the Text}

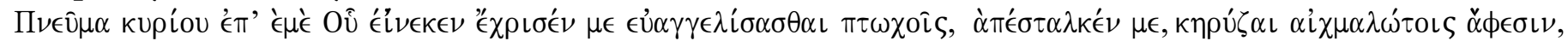

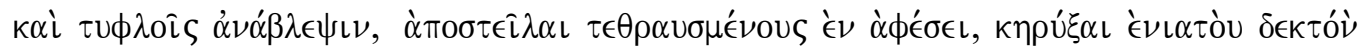

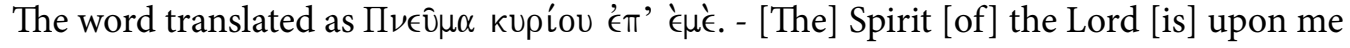

\footnotetext{
4 Henry A. Virkler, Hermeneutics Principles and Processes of Biblical Interpretation (Grand Rapids: Baker Books, 2006$), 73$.

5 Olugbenga, Olagunju. The Relevance of Historical-Critical Method of Biblical Interpretation for the church in Africa. Accessed October 5 , 2020 https://www.academia.edu/23257369/TITLE_THE_RELEVANCE_OF_HISTORICAL_CRITICAL_METHOD_OF_BIBLICAL_INTERPRETATION_FOR_ THE_CHURCH_IN_AFRICA

6 John Barton 'Historical Criticism and Literary Interpretation: Is There Any Common Ground?' In Crossing the Boundaries: Essays in Biblical Interpretation in Honour of Michael D. Goulder, ed. by D. E. Orton et al, 3-16. Biblical Interpretation Series Vol. 8. Leiden: E. J. Brill.

Olagunju, The Relevance of Historical-Critical Method of Biblical Interpretation for the church in Africa.

8 Henry A. Virkler, Hermeneutics Principles and Processes of Biblical Interpretation, (Grand Rapids: Baker Books, 2006 ), 94.

Virkler, Hermeneutics Principles and Processes of Biblical Interpretation, 151.

10 Virkler, Hermeneutics Principles and Processes of Biblical Interpretation, 147.
} 


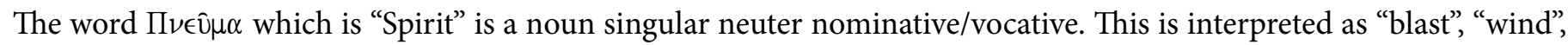
"breath", "the breath of life", "divine inspiration", "a spiritual or immaterial being," and "the spirit" of a man. ${ }^{11} \Pi \nu \in \hat{v} \mu \alpha$, in the concept of the philosophers could denote a minor deity or a demon spirit. ${ }^{12}$ Given such a worldview, it was important for Jesus to identify $\Pi \nu \in \hat{v} \mu \alpha$ as that of the LORD. The Spirit in context is the Spirit of prophetic inspiration as evidenced in the following scriptures "Now there was a man in Jerusalem called Simeon, who was righteous and devout. He was waiting for the consolation of Israel, and the Holy Spirit was upon him" (Lk 2:25). "But as for me, I am filled with power, with the Spirit of the LORD, and with might, to declare to Jacob his transgression, to Israel his sin" (Mic 3:8) and “Then the Spirit of the LORD came upon me, and he told me to say: "This is what the LORD says: That is what you are saying ..." (Eze 11:5). [The] Spirit of the Lord [is] upon me because of which he anointed me..." with the implication that the purpose of ' $\chi \chi \rho\llcorner\sigma \epsilon ́ \nu ~ \mu \epsilon$ 'he anointed me' is to bring about what the main clause refers to, as often in the Septuagint. '́ $\iota \mathcal{V} \in \mathcal{K} \in \mathcal{V}$ when used, in the Septuagint, it indicates the benefit or the advantage as a result of an action that had preceded. In the Septuagint, it is translated "therefore", (Gen. 2:24), "for this cause" (Ex. 9:16) or because (Ps 5:8). It also means by reason of or an account of, in consequence of ${ }^{13} \epsilon^{\prime} \in \mathcal{L} \nu \in \mathcal{L} \in$ is a proposition which expresses cause or reason for something or an action which follows. ${ }^{14}$

" $\chi \rho\left\llcorner\sigma \in \mathcal{~} \nu\right.$ he [has] anointed me is $3^{\text {rd }}$ person singular, aorist active indicative from $\chi \rho ı \omega$ from which $\mathrm{X} \eta \rho\llcorner\sigma \tau o \varsigma$ is derived, "the Anointed One." From the classical usage the term reflects "smearing something on something else." 15 Ritual understanding carries the idea of consecrating and appointing one to a special office. Due to this ceremonial anointing, one is given the capacity and privileges to execute the functions of his office. $\mathrm{X} \rho \mathrm{\omega} \omega$ as a figurative term in reference to the prophets carried the idea of endowments with spiritual gifts, hence the prophets describing themselves as having been anointed consequently appointed to the office of the prophet. In a figurative sense, it implied the endowment of spiritual gifts. Sometimes the term also indicated the presence of the Spirit of the Lord. X $\rho \iota \omega$, a symbolic anointing can be differentiated from $\alpha \lambda \epsilon i \phi \omega$ which was associated with just physical anointing. ${ }^{16}$ Trench states that $\alpha \lambda \varepsilon^{\prime \prime} \iota \varphi \varepsilon \iota v$ is used

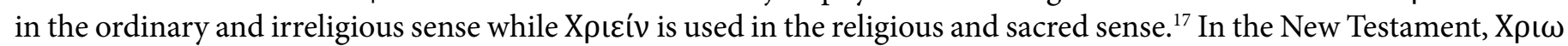
is always an action performed by God. In other words, it is a divine act which carried with it "supernatural sanctions, endowment and blessings." ${ }^{8}$ The word infers "to touch with the hand." Concerning the Messianic ministry and office, it looks at furnishing him with the power needed for the fulfillment of his office. ${ }^{19}$ Thus, Jesus understands the descending of the Spirit upon him as was shown at the baptism (Lk 3:22) as his being anointed with the Spirit.

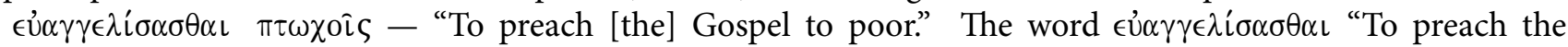
gospel” " is from the verb euaggelizo, which means to bring good news, to announce, evangelize, especially to proclaim the good news of redemption through Jesus. ${ }^{20}$ Again, $\epsilon \dot{\omega} \alpha \gamma \gamma \epsilon \lambda i \sigma \alpha \sigma \theta \alpha \iota$ relates to $\alpha \gamma \gamma \varepsilon \lambda$ os with a primary meaning of a messenger ${ }^{21}$ carrying a message of a military victory as good news from the battlefield. Since $\varepsilon v \alpha \gamma \gamma \varepsilon \lambda i^{\sigma} \sigma \alpha \sigma \theta \alpha \mathrm{l}$,

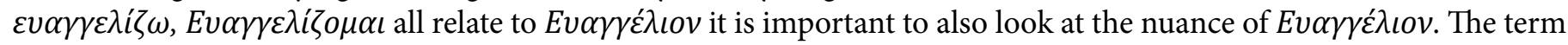
stood for the message itself. Ev $\alpha \gamma \gamma \varepsilon \lambda i \zeta o \mu \alpha$ เ is understood in the New Testament as an event locked in salvation history. Ev $\alpha \gamma \gamma \varepsilon \lambda i \zeta o \mu \alpha \iota$ should be understood as an eschatological preaching in Isaianic perspective. ${ }^{22}$ The verb $\epsilon \cup \alpha \gamma \gamma \epsilon \lambda \iota \zeta o \mu \alpha \iota$ ("preach good news") is a key term in the narrator's description of Jesus' mission. This is supported by a comparison of Luke with Matthew and Mark. The noun $\epsilon \dot{v} \alpha \gamma \gamma \epsilon \in \lambda$ เov never appears in Luke and in Acts only two times, while the verb $\epsilon \cup \alpha \gamma \gamma \epsilon \lambda_{\iota} \zeta o \mu \alpha \iota$ is frequent in Luke. In contrast, Matthew and Mark use the noun fairly frequently, while the verb occurs

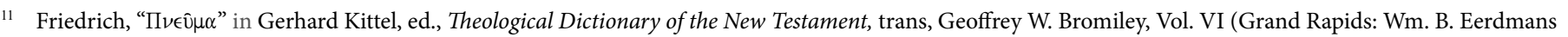
Publishing Company, 1978), 332

12 Thoralf Gilbrant, ed., The Complete Biblical Library: The New Testament Greek-English Dictionary, Delta-Epsilon (Springfield: The Complete Biblical Library, 1991), 228.

13 James Strong, The New Strong's Expanded Exhaustive Concordance of the Bible (Nashville: Thomas Nelson Publishers, 2001 ), 88.

14 Frederick William Danker with Kathryn Krug, The Concise Greek-English Lexicon of the New Testament (Chicago: The University of Chicago Press, 2009), 128.

15 Friedrich, “ $\chi \rho ı \omega ”$ in, Gerhard Kittel, ed., Theological Dictionary of the New Testament, trans, Geoffrey W. Bromiley, Vol. IX (Grand Rapids: Wm. B. Eerdmans Publishing Company, 1977), 494.

16 W. E. Vine, An Expository Dictionary of New Testament Words (Old New Jersey: Fleming H. Revell Company, 1966), 58-59. A $\lambda \epsilon i \phi \omega$ is a general term used for an anointing of any kind, whether of physical refreshment after washing (Ruth 3:3; Sam 12:20; Dan 10:3; in the New Testament (Mt 6:17; Jn 11:2; or of the sick Mk 6:13; Jas 5:14; or dead body (Mk 16:1). But Cvriw is more limited in its use than aleivfw.. It is confined to sacred and symbolic anointings; of Christ as the Anointed of God (Lk 4:18; Ac 10:38 and Heb 1:9), where is it used metaphorically in connection with 'oil of gladness.' ; Gilbrant, international editor, The Complete Biblical Library: The New Testament Greek-English Dictionary, Alpha-Gamma, 528.

17 Richard C. Trench, Synonyms of the New Testament, $8^{\text {th }}$ ed. (Greenwood: The Attic Press, 1961), 39

18 Johannes P. Louw and Eugene A. Nida, eds. "Greek-English Lexicon of the New Testament Based on Semantic Domains" in Gilbrant, ed., The Complete Biblical Library: The New Testament Greek-English Dictionary, Sigmas-Omega, 530.

19 Joseph H. Thayer, Thayer's Greek-English Lexicon of the New Testament (Peabody: Hendrickson Publishers, 2005$), 673$.

20 Mickelson's Enhanced Strong's Dictionaries of the Greek and Hebrew Testaments.

21 "euvvaggeli,sasqai“in” Gerhard Kittel, ed., Theological Dictionary of the New Testament, trans, Geoffrey W. Bromiley, Vol 1 A-G (Grand Rapids: Wm. B. Eerdmans Publishing Company, 19777),74.

22 Gilbrant, ed., The Complete Biblical Library: The New Testament Greek-English Dictionary, Delta-Epsilon, 623. See Thayer, Thayer Greek Lexicon, 256. According to Thayer, the idea of euvvaggeli,sasqai is used specifically to bring to one the good tidings concerning Jesus as the Messiah. 
only once in Matthew (Mt 11:5). Lukan usage may show the influence of Isa 61:1 LXX and other passages in Isaiah

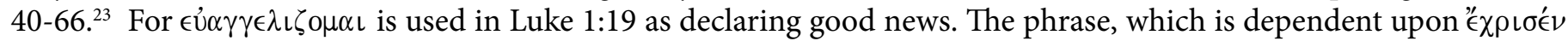

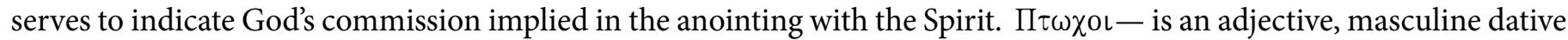
plural means beggars (as cringing), a pauper. (figuratively) distressed. (literally, as a noun) strictly denoting absolute or public dependency on charity. ${ }^{24}$ Here, as often in the Old Testament, it does not denote people who are only economically poor but people who have little or nothing to expect from the circumstances which determine their life and are therefore dependent upon God. ${ }^{25}$ The omission of the article before ptoochois (as before the other nouns in this verse) shows that the reference is not to one specific group but to people who are in this situation generally. It is plural and there is no article, so not "the poor" but rather "beggars". Therefore, the "poor" to whom Jesus was sent was a generalization, not

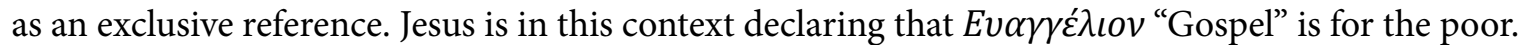

$\grave{\alpha} \pi \epsilon \in \tau \tau \alpha \lambda \kappa \epsilon ́ v$-" he has sent me" is a 3rd person perfect active indicative of $\alpha \pi 0 \sigma \tau \varepsilon \lambda \lambda \omega$ means to set apart. (by implication) to send out, to send off, to send away or dispatch (properly) to send out on a mission. ${ }^{26}$ A

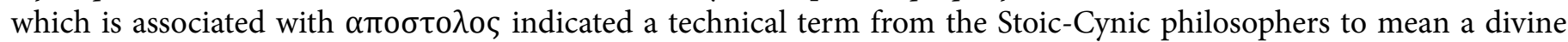
authorization. ${ }^{27}$ There is a sending and task motif in the understanding of the philosophic world into which the Divine word was spoken. From the circle of philosophical expression and understanding of $\alpha \pi \circ \sigma \tau \varepsilon \lambda \lambda \omega$ and $\alpha \pi о \sigma \tau o \lambda \circ \varsigma$

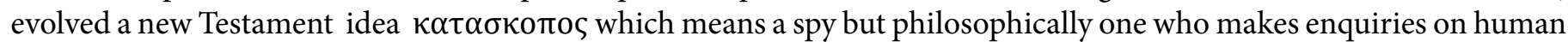
conditions and circumstances in order to bring a message of help from the gods to those in need. ${ }^{28}$ The nature of the verb implies a past action with a present effect. Therefore, having been sent Jesus had divine authorization to make an enquiry into the human circumstances in order to bring solution or message of help to the one who sent him. On this

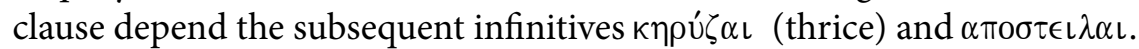

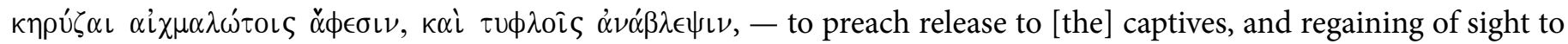
[the] blind.

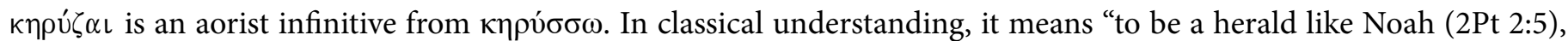
"to proclaim a victory message", to announce, declare, to summon or decree. Having been adopted into the religious vocabulary of Hellenistic Greek, the term is understood as a proclamation of the victor's honours in the sacral games. Due to versatility of $\kappa \eta \rho v \sigma \sigma \omega$, it would be too limited to preach a well-organized sermon. An understanding of the word to mean an announcing, summoning, declaring and demonstrating the arrival of the kingdom of God in Jesus is appropriate. ${ }^{29}$ That is to say Jesus had the anointing sent by God to proclaim a victory message, to declare and show

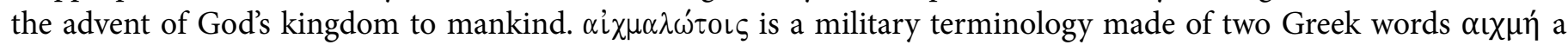
sword and $\alpha \dot{\lambda} \omega \sigma \mathrm{\iota} \varsigma$ a captive. The term thus means one "captured by spear," or "a prisoner of war." It is adjective plural masculine dative. "Captive" is the adjective, $\alpha i \chi \mu \alpha \lambda \omega$ ioเৎ meaning "taken by the spear", "captive" and "prisoner." This alludes to the people of Israel, both as captive exiles and as prisoners of Satan in spiritual bondage. Kittel enforces this by saying that "the prisoner of war" in this context is a wretched person who is greatly in need of the assistance of God. ${ }^{30}$ This expression from the Septuagint means "one going into exile"31 In Lukan context as discussed, the term may imply spiritual prisoners of war. The inimical conditions are not yet identified by the author but the context shows a spiritual indebtedness to a supreme being. $\check{\alpha} \phi \epsilon \sigma \iota \nu$ is the object of the aorist infinitive $\kappa \eta \rho v ́ \xi \alpha$. The main stem is $\alpha \varphi \varepsilon \sigma \iota c$. It is a noun singular famine accusative. The word primarily means a removal, (figuratively) a pardon, a release (from guilt and penalty), forgiveness, deliverance, suspension of punishment. Used figuratively in classical Greek, $\check{\phi} \phi \in \iota \nu$ from $\alpha \varphi i ́ n \mu \mathrm{is}$ a legal term meaning to release one from a legal obligation most significantly about forgiving or cancellation of debt. The usage of it in this text has a sense of liberation and it includes the thought of forgiveness. ${ }^{32}$ In the Septuagint, the meaning of the word focuses on cancellation of debts or releasing of debtors in the Year of Jubilee (Deut. 15:2). ${ }^{33}$ In context of Luke, Jesus anointed by the Spirit, came with the declaration, proclamation, and announcement of release, forgiveness,

\footnotetext{
${ }^{23}$ Isa. 40:9; 52:7; 60:6. These four Isaiah passages use the verbal stem, while the noun evayy3 $\lambda$ iou does not occur in Isaiah LXX and is rare in the LXX as a whole. Not only lsa. 61:1 but also 52:7 may be important to the narrator, for Acts 10:36 seems to be influenced by it.

24 Mickelson's Enhanced Strong's Dictionaries of the Greek and Hebrew Testaments.

25 Alan Richardson, A Theological Word Book of the Bible (Virginia: Macmillan Pub Co, 1962), 168.

26 Mickelson's Enhanced Strong's Dictionaries of the Greek and Hebrew Testaments.

7 Gilbrant, ed., The Complete Biblical Library: The New Testament Greek-English Dictionary, Sigmas-Omega, 401.

Gilbrant, ed., The Complete Biblical Library: The New Testament Greek-English Dictionary, Sigmas-Omega, 401.

Gilbrant, ed., The Complete Biblical Library: The New Testament Greek-English Dictionary, Sigmas-Omega, 338-339.

30 Friedrich, “aivcmalw,toic” in, Gerhard Kittel, ed., Theological Dictionary of the New Testament, trans, Geoffrey W. Bromiley, Vol. IX (Grand Rapids: Wm. B. Eerdmans Publishing Company, 1977),195.

31 Gilbrant, ed., The Complete Biblical Library: The New Testament Greek-English Dictionary, Alpha-Gamma,121.

32 Friedrich, "a..,fesin" in Gerhard Kittel, ed., Theological Dictionary of the New Testament, trans, Geoffrey W. Bromiley, Vol. VI, 511.

Gilbrant, ed., The Complete Biblical Library: The New Testament Greek-English Dictionary, Alpha-Gamma, 498.
} 
deliverance, and suspension of judgment. Anyone who receives the Gospel has been cleared of any punishment, or debt therefore there is freedom from the captors. $k \alpha \iota$ is a conjunction meaning "and, even, also." It is sometimes used in modifying a word. ${ }^{34}$ The context of a sentence determines how $\kappa \alpha \iota$ is translated. The "and" meaning is used in Matt 2:2,3. 11, 4:22. In Matt 5:39, $\kappa \alpha \iota$ means "also" (Mt 10:30, Jn 8:19, 1Cor 11:6). Sometimes, $\kappa \alpha \iota$ means 'but' (Mt 11:19). Kai is also used to introduce an apodosis of a sentence (Jas 2:4, Gal 3:28). ${ }^{35} \mathrm{~K} \alpha \mathrm{L}$ is used twice in Matt 6:12. The $\mathrm{K} \alpha \mathrm{L}$ in the phrase

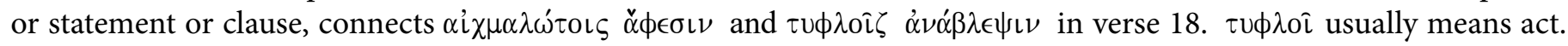
"to make blind," "to rob of eyesight." ${ }^{6} 6$ The word $\tau \cup \phi \lambda \circ \hat{\imath} \varsigma$,, is adjective masculine dative form of $\tau \cup \varphi \lambda \circ \varsigma$ meaning to the ones with inability to see or perceive literally or figuratively. It is said that the Qumran community excluded the blind from their fellowship since blindness was considered to be the judgment of God. ${ }^{37}$ In the context of Luke, blind people are seen as socially weak and personally unhappy (Lk 14:13:21). They are among the specific objects of Jesus' Messianic

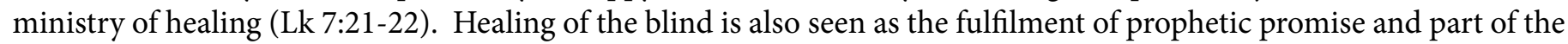
miracles that signals the eschatological age of salvation. So, in this case the message Jesus preached serves as light to the world (Jn 1:9).

$\dot{\alpha} \nu \alpha \dot{\beta} \lambda \epsilon \in \psi \nu$ is a compound verb from $\alpha \nu \alpha$ which means "up, again"and $\beta \lambda \varepsilon \pi \omega$ "I see". $\alpha \nu \alpha \dot{\beta} \beta \epsilon \tau \omega$ is therefore, "I look up, receive sight," ${ }^{38}$ 'recovery of sight', or, with a shift from the abstract to the concrete, "new eyes."39 From classical point of understanding, it means "look up", "see again, and regain sight." When used in a metaphorical sense, it implies being revived..$^{40} \mathrm{H}$. G. Liddell and R. Scott define $\alpha \nu \alpha \dot{\alpha} \beta \lambda \epsilon \nu \nu$ as "looking up" as a mark of confidence..$^{41} \beta \lambda \in \pi \omega$ has as strong emphasis on the function of the eye. In reference to the sense aspect, $\beta \lambda \in \pi \omega$ means to note something to be intent on something. It may also be used in reference to conceptual or perception and in an abstract sense also to have an insight. ${ }^{42}$ The term in context therefore carries the idea of Jesus anointed by the Spirit who came to bring sight to those who are blinded by false teachings. Thus, he was anointed by the Spirit to bring revival to those who had been weakened and could not see the light of God. It also indicates that Jesus had been anointed by the Spirit to cause people to regain confidence.

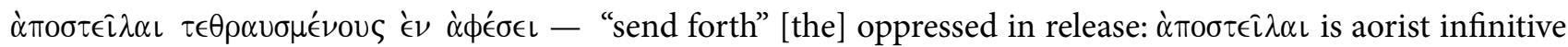
related to $\alpha \pi 0 \sigma \tau \in \lambda \lambda \omega$ meaning to send away, ${ }^{43}$ to send off, to send to dispatch - it is the origin of the word "apostle." The word carries the basic idea of $\alpha \pi \varepsilon \sigma \tau \alpha \lambda \kappa \varepsilon v,{ }^{44}$ above and brought in here from Isa 58:6.

Here $\alpha \pi 0 \sigma \tau \epsilon \lambda \lambda \omega$ is used in a weaker meaning ('to let go' without indication of purpose or commission). $\dot{\alpha} \phi \epsilon \in \epsilon \iota$ does not refer (as does $\check{\alpha} \phi \epsilon \sigma \iota \nu$ above) to the release of captives but to a freedom in a social and religious sense which is the opposite of the state to which $\tau \in \theta \rho \alpha \nu \sigma \mu \mu^{\prime} \nu$ ov refers. $\tau \in \theta \rho \alpha \nu \sigma \mu \mu^{\prime} \nu$ ov - "the oppressed" is a perfect participle, accusative plural from the verb $\theta \rho \alpha \nu \omega$ means the ones who have been bruised. $\theta \rho \alpha \nu \omega$ simply means break in pieces, shatter or weaken. ${ }^{45}$ The wounded enjoys a fleeing without interjection because Jesus is leading an escape into a field of freedom. ${ }^{46}$ The complex nature of the phrase $\dot{\alpha} \pi 0 \sigma \tau \epsilon \hat{\imath} \lambda \alpha \iota \tau \epsilon \theta \rho \alpha \nu \sigma \mu \epsilon \in \nu 0 \cup \varsigma \dot{\alpha} \phi \epsilon \sigma \epsilon L$, requires that before the bruised can be sent away or freed, the bruises should be dressed or better healed before they can flee. In the same vein, Isaiah 58 gives further perspective on the ones needing release. Not only they are like people captive "in a foreign land as consequence

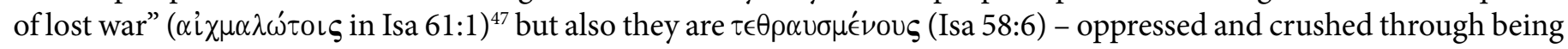
treated "very harshly" so that they are now "heavily in debt." 48

The theology of Luke clarifies the point. Luke 3:15-18 talks about the Stronger One to appear who is superior to John the Baptist. The one coming comes with him the Spirit's baptism, which is a representation of the presence of

\footnotetext{
34 Maurice A. Robinson and Mark A. House (eds.), Analytical Lexicon of New Testament Greek Revised and Updated (Peabody, Massachusetts: Hendrickson Publishers), 187.

35 William D. Mounce, The Analytical Lexicon of the Greek New Testament (Grand Rapids, Michigan: Zondervan Publishers, 1993 ), 259.

36 Friedrich, "tufloi/ $\varsigma$ “in Gerhard Kittel ed., Theological Dictionary of the New Testament, trans, Geoffrey W. Bromiley, Vol VIII (Grand Rapids: Wm. B. Eerdmans Publishing Company, 19777), 270.

37 Gilbrant, international editor, The Complete Biblical Library: The New Testament Greek-English Dictionary, Sigma-Omega, 330.

38 William D. Mounce, Basics of Biblical Greek Grammar (Grand Rapids: Zondervan Publishing House, 2003), 415

39 UBS New Testament Handbook Series. Copyright (c) 1961-1997, by United Bible Societies.

40 Gilbrant, The Complete Biblical Library: The New Testament Greek-English Dictionary, Alpha-Gamma, 208.

41 H. G. Liddell and R. Scott, A Greek-English Lexicon, 9th ed. Ed. by H. Stuart Jones and R. McKenzie in Thoralf Gilbrant, international editor, The Complete Biblical Library: The New Testament Greek-English Dictionary, Alpha-Gamma, (Springfield: The Complete Biblical Library, 1990), 208.

42 Friedrich, "blepw" in Gerhard Kittel, ed., Theological Dictionary of the New Testament, trans, Geoffrey W. Bromiley, Vol. VI, (Grand Rapids: Wm. B. Eerdmans Publishing Company, 1967), 317

43 Max Zerwick S. J. -Mary Grosvenor, A Grammatical Analysis of the Greek New Testament, unabridged, 5th Revised Edition (Roma: Editrice Ponitificio Instituto Biblico, 1996), 186.

44 Gilbrant, ed., The Complete Biblical Library: The New Testament Greek-English Dictionary, Alpha-Gamma, 401.

45 Gilbrant, ed., The Complete Biblical Library: The New Testament Greek-English Dictionary, Zeta-Kappa, 119.

46 Zerwick and Grosvenor, A Grammatical Analysis of the Greek New Testament, unabridged, 5th Revised Edition, 186.

47 T. Muraoka, A Greek-English Lexicon of the of the Septuagint (Louvain: Peeters, 2009), 18.

48 Muraoka, Lexicon of LXXX, 331-332, who cites the same word being used in Deut 28:33 to describe those would be "wronged and battered" (avdikouvmenos kaiv teqrausmenous) by their foreign conquerors.
} 
salvation and the covenant's arrival (Jer 31:31). As a result, the narrative gives a description to a messianic function. This again clarifies the reason why Isaiah 58 was added to the list. This certifies that the mission of Jesus is observed in messianic terms. ${ }^{49}$ Jesus' healings observe this release and connect to his power, and that is superior to prophetic power. Jesus comes to bring into fulfillment what the people of Israel could not do as recorded in Isaiah 58 and was reprimanded on that: Jesus will meet in love the needs of those who need God. The image is of Jesus reaching out to those in need and assisting them. It is a pronouncement of inequality overturned. ${ }^{50}$

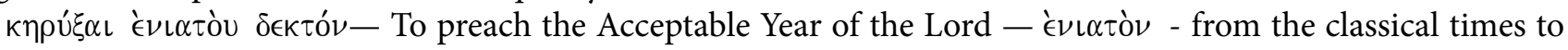
the patristic age, the word has been understood as a year's length of time. In the ancient times, '̇vL $\alpha$ iò $\nu$ had a contractual significance which in rental agreements had the lending specified that "a year from today." $\delta \in \kappa \tau o ́ v$ is from $\delta \in \kappa \tau o ́ s$, which carries the idea of recognition or favourable. ${ }^{51}$ In context, it modifies '́ $\nu$ L $\alpha$ tò $\nu$ as seen in verse 24 and the following other scriptures (Ac 10:35; 2 Co 6:2; Phi 4:18). In the New Testament, especially, Luke 4:19, one should think in terms of Messianic eschatology. That is to say, Jesus claimed that He was the fulfilment of this influential text. This is because the pronoun ' $m$ e' is emphasized three times in verse 18 in the Greek text: Jesus succeeds in riveting everyone's attention on Him (verse 20b). We should also note that the "Acceptable Year of the Lord "which Jesus is sent to proclaim is closely connected with the "reign of God" $\beta \alpha \sigma \iota \lambda \in i \alpha \nu$ (Lk 4:43) within which Jesus has been granted royal authority by his Father (Lk 22:29-30).

\section{The Meaning of Luke 4:18-19}

[The] Spirit [of] the Lord [is] upon me - The quotation commences with a allusion to the speaker's anointing with God's Spirit. The Spirit has been repeatedly mentioned since Luke (Lk 3:22; 4: 1, 14), and his emphasis on Jesus aims at a distinct anointing and an exceptional task: an appointment to perform the mission of God in the best interests of people. Considering the analysis of the text, the primary emphasis is that Jesus claims to be the Isaianic Messiah full of the Spirit of the Sovereign LORD for a specific mission. It must be noted that there is a difference between the one anointing and the Spirit. The Hebrew text gives a clearer distinction "The Spirit of the Sovereign/Lord God [is] upon me. The LORD anointed me..." The Greek version puts it this way:" The Spirit of the Lord [is] upon me because of which he anointed me..." Jesus identifies himself as the subject of Isaiah's prophetic word. As such he is (l) the bearer of the spirit (v. 18); (2) the eschatological prophet, proclaimer of the "good news"; and (3) the one who brings release to the oppressed (a messianic function). All the gifts and graces of the Spirit were conferred upon him, not by measure, as upon other prophets, but without measure (Jn 3:34). "THE SPIRIT OF THE LORD is upon Me," have been noted since the days of the Church Fathers, as an illustrious example of Father, Son, and Holy Ghost being exhibited as in distinct yet harmonious action in the scheme of salvation..$^{52}$

Because he has anointed me, and sent me. - The descent of the Spirit on Jesus is interpreted as an event in which God "ecrisen" anointed Jesus (Lk 3:21-22). This anointing implied that Jesus had been set part and qualified for a task. Part of the task was to "preach [the] Gospel to the poor." The anointing here refers to what Luke described later in Acts 10:38 about how Jesus was filled and empowered by the Holy Spirit. The text reveals that the activities purposed for the Spirit upon Jesus are orchestrated by the Lord. All the same, it can be summarized this way; the Lord approves and sends Jesus, the Spirit empowers Jesus, and Jesus performs.

To preach [the] Gospel to [the] poor - to preach the Gospel in context means to proclaim or herald the message of salvation or deliverance for God's people. In effect, Jesus proclaims himself as the content or the object of the message which is for all people. ${ }^{53}$ This Gospel, which is declared in the context, is that Jesus has come to bring the promises of God into fulfillment to Israel, and now the way of salvation is open to all. It is therefore clear that the mission of Jesus is focused on the destitute - defined not merely in subjective, spiritual or economic terms, but in the holistic sense of those who are for any of a number of socio-religious reasons are in need of God's intervention. ${ }^{54}$ Thus, the "poor" to whom Jesus was sent was a generalization, not as an exclusive reference. This position is supported by Bock who described the poor in context as a "soteriological generalization"- that is, those who most often responded to Jesus (1 Cor. 1:26-29),

\footnotetext{
49 Bock, Baker Exegetical Commentary on the New Testament Luke 1:19:50, 109. In Isaiah, the announcement of the prophet coincides with the salvation, but the deliverance is God's, not the prophet's (Isa 40:8-11; 58:6-8).

50 W.E. Pilgrim, Good News to the Poor: Wealth and Poverty in Luke-Acts, (Minneapolis: Augsburg, 1981 ),70.

51 Gilbrant, The Complete Biblical Library: The New Testament Greek-English Dictionary, Delta-Epsilon, 41.

52 Robert Jamieson et al, The Bethany Parallel Commentary on the New Testament (Minneapolis: Bethany House Publishers, 1983 ), 372.

53 This is in consistence with Luke's purpose which was to emphasise that Jesus is the Saviour of all and exegetical analysis of the text which "Me" evme, or me occurs three times in the first half of the quotation.

54 This is consistent with the exegesis and the Authorial Intent and Original Audience Understanding (see page 10)
} 
and in an invitation context it refers to those who are open to God. ${ }^{55}$ They characterize concretely the person in need. Fitzmyer underscores this position by affirming that "to the poor, Isaiah was announcing the Consolation of Zion to various groups in the postexilic community," ${ }^{\prime 6}$ This demystifies the position of the Olfords who limited the interpretation of poor in context to economic disadvantage. Three things to be preached by Jesus in relation to the text include the following:

(i) To preach release to [the] captives, and regaining of sight to [the] blind - the Gospel proclaims liberty, such as that of Israel in Egypt and Babylon. In the Old Testament, the exiled were those that were referred to as captives, however, it often carried spiritual overtones, particularly as OT regarded the outcast as sinful (Deut 28-32; Ps 79:11; 126:1; Isa 42:7). The image is of release from captivity; but in Luke, the picture symbolizes enslavement to sin and Satan (Lk 1:77; 7:47; 24:47). Jesus in Luke's Gospel gave freedom to people who were captives to all sorts of bondage. There are a number of examples of this kind of captives being set free by the Lord. For example: Set free from guilt (Lk 7:41-50); the love of money (Lk 19:1-10) and among others. The Messiah was divinely commissioned to preach and to bring about release from this captivity (Jn 8:36). regaining of sight to [the] blind - the narrative clarifies the issue of physical healing, however, it is a metaphorical presentation of receiving revelation and come into contact with salvation and being part of the family of God (Lk 1:78-79; 10:23-24; 18:41-43). This position conflicts with Esler who limits the proclamation of "regaining of sight to the blind" in (Lk 4:18) to the physical healing of the blind people in the eastern part of the Roman Empire with the explanation that the life of blind people in this particular place was dependent entirely on begging; hence they needed empowerment.

(ii) To send forth [the] oppressed in release - The Jews understood this text in reference to their deliverance from Roman rule by the promised Messiah. This is because the Lukan text promises to overcome oppression, suffering, poverty, and exploitation, among others. Jesus in this context presented himself as the answer to all the ills that oppress humanity. Through exorcism and healing ministry, those that were oppressed by the devil in varying forms such as, madness, ailments, and evil attacks were set free by Jesus.

(iii) To preach the Acceptable Year of the Lord - undoubtedly links the narrative to the Jubilee theme (appears also in 2 Co 6:2 and Isa 49:8). Due to the broad character of the relief that Isaiah explained, Jubilee, in Judaism referred to the beginning of new period of God. The citation in Luke, then, is not a call to fulfill literally the legal requirement of Jubilee. Preferably, the narrative takes that image of freedom to demonstrate what God is doing spiritually and physically through his commissioned agent, Jesus. Jubilee, by analogy, becomes a picture of total forgiveness and salvation, just as it was written in its prophetic usage in Isaiah 61. This narrative justly pictures Christ's conception of his mission and message. The Year of Jubilee allowed for a new start (Lev. 25:10). Jesus offers a total cancellation of spiritual debt and a new beginning to those who respond to His message.

\section{RECOMMENDATIONS}

In the light of the discussion above, the paper recommends that the proper interpretation of Scripture using the right tools should be adopted in order to ascertain the accurate meaning of biblical texts such as Luke 4:18-19, for application. Just as Jesus, identified himself with the Promised Messiah in the Isaianic prophecies and carried out his ministry in line with God's purposes, so also, Christian ministers should identify themselves with Jesus and his ministry in order to be relevant in the contemporary world. Therefore, present-day's ministers should be conversant with the right tools for biblical interpretation, obtaining commentaries, Bible Dictionaries and other study helps and also possess a command of biblical languages.

\section{CONCLUSION}

This paper has presented an exegetical analysis of Luke 4:18-19. Historical Critical Method of interpretation as an exegetical approach was employed to cover political, social, religious and cultural background of the pericope in order to understand the world behind the Text. To be able to unravel approximate intended meaning of the original author, the study employs morpho-syntactic analysis approach to determine more accurately the author's intended meaning of the text. The paper concludes that Jesus claims to have been sent by God to accomplish the task of preaching salvation to humanity. His identification with the promised Messiah in the Isaianic prophecies indicates that he was commissioned

\footnotetext{
5 Darrel Bock, Luke 1:1 - 9:50 Baker Exegetical Commentary on the New Testament (Grand Rapids: Baker Academic, 1994$), 408$.

56 Joseph A. Fitzmyer, The Gospel According to Luke I-IX: Introduction, Translation, and Notes, The Anchor Bible, vol. 28 (New Haven: Yale University Press, 2008 ), 532-533.
} 
and empowered to carry out a holistic ministry which involves not only preaching salvation but also meeting social needs of people he encountered.

\section{ABOUT AUTHORS}

Patrick Yankyera is the Senior Pastor of the Rhema Assemblies of God Church, Ahinsan Kumasi. He is currently a PhD candidate in the Department of Religious Studies, Kwame Nkrumah University of Science and Technology- Kumasi Ghana.

Jonathan Edward Tetteh Kuwornu-Adjaottor is an Associate Professor of New Testament and Mother Tongue Biblical Hermeneutics in the Department of Religious Studies, Kwame Nkrumah University of Science and Technology - Kumasi Ghana.

Emmanuel Kojo Ennin Antwi is a Senior Lecturer in the Department of Religious Studies, Kwame Nkrumah University of Science and Technology - Kumasi Ghana.

Frimpong Wiafe is a Senior Lecturer in the Department of Religious Studies, Kwame Nkrumah University of Science and Technology - Kumasi Ghana.

\section{BIBLIOGRAPHY}

Bock, L. Darrel. Luke 1:1 - 9:50 Baker Exegetical Commentary on the New Testament. Grand Rapids: Baker Academic, 1994.

Barton, John. 'Historical Criticism and Literary Interpretation: Is There Any Common Ground?' In Crossing the Boundaries: Essays in Biblical Interpretation in Honour of Michael D. Goulder, ed. by D. E. Orton et al, 3-16. Biblical Interpretation Series Vol. 8. Leiden: E. J. Brill.

Danker, Frederick William with Krug, Kathryn. The Concise Greek-English Lexicon of the New Testament. Chicago: The University of Chicago Press, 2009.

Fitzmyer, J. A. The Gospel According to Luke I-IX: Introduction, Translation, and Notes, The Anchor Bible, vol. 28. New Heaven: Yale University Press, 2008.

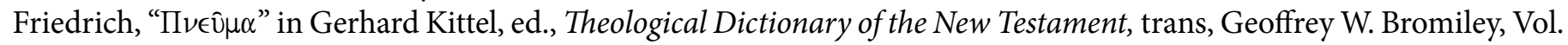
VI. Grand Rapids: Wm. B. Eerdmans Publishing Com $\beta \lambda \in \pi \omega$ pany, 1978.

Friedrich, " $\beta \lambda \epsilon \pi \omega$ " in Gerhard Kittel, ed., Theological Dictionary of the New Testament, trans, Geoffrey W. Bromiley, Vol. VI. Grand Rapids: Wm. B. Eerdmans Publishing Company, 1967.

Friedrich, " $\chi \rho 1 \omega$ " in, Gerhard Kittel, ed., Theological Dictionary of the New Testament, trans, Geoffrey W. Bromiley, Vol. IX. Grand Rapids: Wm. B. Eerdmans Publishing Company, 1977.

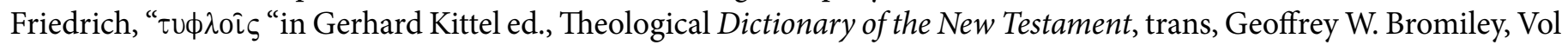
VIII. Grand Rapids: Wm. B. Eerdmans Publishing Company, 1977.

"€ن̉ $\alpha \gamma \gamma \in \lambda i \sigma \alpha \sigma \theta \alpha \iota$ "in" Gerhard Kittel, ed., Theological Dictionary of the New Testament, trans, Geoffrey W. Bromiley, Vol 1 A-G. Grand Rapids: Wm. B. Eerdmans Publishing Company, 1977.

Gilbrant, Thoralf. ed., The Complete Biblical Library: The New Testament Greek-English Dictionary, Alpha-Gamma. The Complete Biblical Library: The New Testament Greek-English Dictionary, Delta-Epsilon. The Complete Biblical Library: The New Testament Greek-English Dictionary, Zeta-Kappa The Complete Biblical Library: The New Testament Greek-English Dictionary, Sigmas-Omega

Green, B. Green. The Gospel of Luke. Grand Rapids: William B. Eerdmans Publishing Company, 1997. The New International Commentary on the New Testament: The Gospel of Luke. Grand Rapids: William B. Eerdmans Publishing Company, 2013. Why Mission? Maryland: Abingdon Press, 2015.

Hendriksen, William. New Testament Commentary: Exposition of the Gospel According to Luke. Grand Rapids: Baker Academic, 2007.

Horton, M. Stanley. Acts: A Logion Press Commentary. Springfield: Gospel Publishing House, 2001.

Jamieson, Robert et al, The Bethany Parallel Commentary on the New Testament. Minneapolis: Bethany House Publishers, 1983.

Kistemaker, J. Simon. Exposition of the Acts of the Apostles. Grand Rapids: Baker Books House, 1990. 
Liddell, H. G. and Scott, R. A. Greek-English Lexicon, 9th ed. Ed. by H. Stuart Jones and R. McKenzie in Thoralf Gilbrant, ed., The Complete Biblical Library: The New Testament Greek-English Dictionary, Alpha-Gamma. Springfield: The Complete Biblical Library, 1990.

Louw, P. Johannes. and Nida, A. Eugene. eds. "Greek-English Lexicon of the New Testament Based on Semantic Domains" in Gilbrant, ed., The Complete Biblical Library: The New Testament Greek-English Dictionary, Sigmas-Omega, 530. https://doi.org/10.2307/3267199

MacDonald, William. Bible Commentary. Nashville: Thomas Nelson Publishers, Inc, 1995.

Marshall, I. Howard. Luke: Historian and Theologian (Gospel Profile 3). London: Paternoster Press, 2006.

Mickelson's Enhanced Strong's Dictionaries of the Greek and Hebrew Testaments.

Mounce, D. William. Basics of Biblical Greek Grammar. Grand Rapids: Zondervan Publishing House, 2003.

Muraoka, T. A Greek-English Lexicon of the of the Septuagint. Louvain: Peeters, 2009.

Olugbenga, Olagunju. The Relevance of Historical-Critical Method of Biblical Interpretation for the church in Africa. Accessed October 5, 2020 https://www.academia.edu/23257369/TITLE_THE_RELEVANCE_OF_HISTORICAL_CRITICAL_ METHOD_OF_BIBLICAL_INTERPRETATION_FOR_THE_CHURCH_IN_AFRICA

Richardson, Alan A Theological Word Book of the Bible. Virginia: Macmillan Pub Co, 1962.

Robinson A. Maurice. and House A. Mark (eds.), Analytical Lexicon of New Testament Greek Revised and Updated. Pea body, Massachusetts: Hendrickson Publishers. https://doi.org/10.1108/09504121311308499

Roth, S. John. The Blind, the Lame, and the Poor: Character Types in Luke-Acts. Sheffield: Sheffield Academic Press, 1997.

Scobie, H.H. Charles "A Canonical Approach to Interpreting Luke," in Reading Luke: interpretation, Reflection, Formation, ed. Craig Bartholomew, Joel B. Green, and Anthony Thiselton, Scripture and Hermeneutics 6. Milton Keynes: Paternoster, 2005.

Stamp, Donald and Adams J. Wesley. Fire Bible: Global Edition. Springfield: Hendrickson Publishers Marketing, LLC, 2009.

Strong, James. The New Strong's Expanded Exhaustive Concordance of the Bible. Nashville: Thomas Nelson Publishers, 2001.

Stronstad, Roger. The Prophethood of All Believers: A Study in Luke's Charismatic Theology. Sheffield: Sheffield Academic Press, 1999.

Tannehill, C. Robert. The Narrative Unity of Luke-Acts A Literary Interpretation volume one. The Gospel according to Luke. Philadelphia: Fortress Press, 1991. https://doi.org/10.1177/014610798801800117

Thayer, H. Joseph. Thayer's Greek-English Lexicon of the New Testament. Peabody: Hendrickson Publishers, 2005.

Trench, C. Richard. Synonyms of the New Testament, $8^{\text {th }}$ ed. Greenwood: The Attic Press, 1961.

UBS New Testament Handbook Series. Copyright @ 1961-1997, by United Bible Societies.

Uwaegbute, Kingsley Ikechukwu “A Challenge of Jesus' Manifesto on Luke 4:16-21 to Nigerian Christians," in International Journal of Theology \& Reformed Tradition, Vol. 5, 145.

Vine, W. E. An Expository Dictionary of New Testament Words. Old New Jersey: Fleming H. Revell Company, 1966.

Virkler, Henry A. Hermeneutics Principles and Processes of Biblical Interpretation. Grand Rapids: Baker Books, 2006. https://doi.org/10.1177/004057368203900128

William D. Mounce, The Analytical Lexicon of the Greek New Testament (Grand Rapids, Michigan: Zondervan Publishers, 1993.)

Zerwick S. J. Max S. -Mary Grosvenor, A Grammatical Analysis of the Greek New Testament, unabridged, 5th Revised Edition. Roma: Editrice Ponitificio Instituto Biblico, 1996. 